УДК $78.03+78.087$

DOI https://doi.org/10.31723/2524-0447-2020-31-2-11

\author{
Олександра Андріївна Овсяннікова-Трель \\ ORCID: 0000-0002-1969-5530
}

кандидат мистецтвознавства, доцент кафедри історії музики та музичної етнографії

Одеської національної музичної академії імені А. В. Нежданової alextrell1973@gmail.com

\title{
АВТОРСЬКЕ СЛОВО КОМПОЗИТОРА ЯК ПЕРЕДУМОВА МУЗИКОЗНАВЧОГО ОСМИСЛЕННЯ СУЧАСНОГО МУЗИЧНОГО МИСТЕЦТВА
}

Метою роботи $є$ визначення методологічного значення авторського слова композитора для музикознавчого дослідження музичного мистецтва на рубежі XX-XXI cm. Методологія дослідження полягає в комплексному використанні музично-історичного та культурологічного підходів до музичного мистецтва сучасності й авторського слова композитора як його суттєвого складника; а також системного, структурно-функціонального методів $і$ компаративістики щодо дослідження автора й авторського слова як провідних категорій гуманітарної культури. Наукова новизна дослідження полягає в музикознавчому осмисленні вербального композиторського дискурсу сучасності в контексті теоретичних підстав розвитку авторології як спеціальної галузі сучасної гуманітаристики, визначено методологічні аспекти вивчення композиторської постаті як суб'єкта та об'єкта музичного мистецтва. Висновки. Орієнтованість сучасного музикознавства на дослідження проблеми автора в музичній творчості та його вербального вираження, шо втілюється в авторському слові композитора, актуалізує методологічні потреби сучасного гуманітарного знання й відображає сучасний стан «науки про музику», яка в умовах глобалізованого світу все більш стає наукою про людину. Кількісне накопичення композиторських вербальних текстів, яке створює на сьогоднішній момент досить масштабну й автономну галузь текстів про музичне мистецтво та культуру загалом, закономірно потребує їх спеціального вивчення і ставить досить специфічні завдання перед музикознавиями. Прагнення почути, зрозуміти й роз'яснити Слово композитора є неодмінною умовою формування суто музикознавчих уявлень про композиторські рефлексії, шо в сучасному музичному мистецтві представлені досить широко й різноманітно. Зазначена настанова, безумовно, сприяє розширенню пізнавальних обріїв музикознавчого дискурсу сучасності в загальному плані, оскільки з методологічного погляду вона може розумітися як те

(C) Овсяннікова-Трель О. А., 2020 
«знаряддя» пізнання, що дає можсливості проникнення в глибинні смисли музичного тексту і творчої індивідуальності композитора, які органічно пов'язані між собою «тайною творчості» й повинні розумітися як «відображення» один одного.

Ключові слова: автор, авторське слово композитора, авторепрезентація, композиторська рефлексія, вербальний текст композитора.

Ovsiannikova-Trel Oleksandra Andriivna, Ph.D. in History of Arts, Associate Professor at the Department of History of Music and Musical Ethnography of the Odessa National A. V. Nezhdanova Academy of Music

The author's word of the composer as a prerequisite for the musicological understanding of contemporary musical art

The purpose of the article is to determine the methodological meaning of the author's word of the composer for the musicological research of musical art at the turn of the XX-XXI centuries. The research methodology consists in the complex use of musical-historical and cultural approaches to the musical art of our time and the author's word of the composer as its essential component; as well as systemic, structural and functional methods and comparative studies for the study of the author and the author's word as the leading categories of humanitarian culture. The scientific novelty of the research lies in the musicological comprehension of the verbal composer's discourse of our time in the context of the theoretical foundations of the development of authorology as a special area of modern humanities, the methodological aspects of studying the creative figure of the composer as a subject and object of musical art are determined. Conclusions. The focus of modern musicology on the study of the author's problem in musical creativity and his verbal expression, which is embodied in the author's word of the composer, actualizes the methodological needs of modern humanitarian knowledge and reflects the current state of the "science of music", which in the conditions of a globalizing world is increasingly becoming a science of man. The quantitative accumulation of composer's verbal texts, which currently creates a fairly large-scale and autonomous area of texts about musical art and culture in general, naturally requires their special study and sets quite specific tasks for musicologists. The desire to hear, understand and explain the composer's word is an indispensable condition for the formation of purely musicological ideas about the composer's reflections, presented quite widely and variedly in modern musical art. This attitude certainly contributes to the expansion of the cognitive horizons of contemporary musicological discourse in general, since from a methodological point of view, it can be understood as a "tool" of cognition, which provides an opportunity to penetrate into the deep meanings of the musical text and the creative personality of the composer as those phenomena that are organically connected between themselves the "secret of creativity" and should be understood as a "reflection" of each other.

Key words: author, author's word of the composer, auto-presentation, composer's reflection, verbal text of the composer. 
Актуальність теми дослідження. Сучасне музикознавство як провідна галузь гуманітарного знання все частіше виявляє інтерес до тієї сторони творчого вираження індивідуальності композитора, що значною мірою розширює можливості розуміння його музики, тому визнається музикознавцями як та, що має суттєве методологічне значення для дослідницької практики. Маються на увазі різноманітні вербальні тексти композиторів, що в словесно-понятійній формі фіксують різні рівні композиторської свідомості й багато в чому сприяють «формуванню цілісного уявлення про постать творця музичних концепцій і культуротворчу спрямованість його авторської свідомості» [5, с. 373]. Зазначені позиції в методологічному плані надзвичайно доцільні щодо дослідження творчості композиторів-репрезентантів сучасного академічного музичного мистецтва. Це пояснюється фактом наявності досить розгорнутого вербального композиторського дискурсу, у якому формуються спеціальні уявлення про художньо-естетичний і музично-мовний образ індивідуального стилю композитора та сучасної музики в цілому.

Метою статті $€$ визначення методологічного значення авторського слова композитора для музикознавчого дослідження музичного мистецтва сучасності.

Наукова новизна дослідження полягає в музикознавчому осмисленні вербального композиторського дискурсу сучасності в контексті теоретичних підстав розвитку авторології як спеціальної галузі сучасної гуманітаристики.

Виклад основного матеріалу. Постать автора є однією з ключових у гуманітарному просторі європейської культури, що зумовило їі концептуальне значення для багатьох гуманітарних наук у силу того, що саме вона $\epsilon$ «першопричиною» виникнення будь якого тексту як форми буття, тією силою, що складає-створює з окремих мовно-структурних елементів візерунки смислу (якщо розуміти поняття тексту в його загальному значенні: від лат. textum - тканина; виткане; сплетіння; зв'язок, з'єднання [8, с. 505; 11]). Цей факт обумовлює наріжне положення автора й авторського слова у вигляді тексту в проблемному полі гуманітарних наук, про що пише М. Бахтін: «Предмет гуманітарних наук - виразне буття, що говорить. Це буття ніколи не збігається з самим собою, тому невичерпно у власному розумінні й значенні» [1, с. 8]. Тому основним завданням гуманітарного дослідження, на думку філософа та літера- 
турознавця, полягає в проблемі розуміння мови й тексту як тих об'єктивацій, що виробляє культура. У гуманітарних науках розуміння проходить через текст - через запитування до тексту, що дає можливості розуміння того, що може лише тільки здаватися: намірів, підстав, причин, задумів автора. Це розуміння глибинного смислу висловлювання рухається в модусі аналізу мови або тексту, які М. Бахтін розуміє як системні явища: «Кожне велике і творче словесне ціле є дуже складною і багатоплановою системою відносин <...>. Елементи мови всередині мовної системи або всередині «тексту» (у суворо лінгвістичному сенсі) не можуть вступати в діалогічні відносини. Чи можуть вступати в такі відносини, тобто говорити один з одним, мови <...>, мовні (функціональні) стилі <...> тощо? Тільки за умови нелінгвістичного підходу до них, тобто за умови трансформації їх у «світогляди» (або якісь мовні або мовні світовідчуття), у «точки зору», у «соціальні голос» тощо. $<\ldots>$ При подібних трансформаціях мова отримує своєрідного «автора», мовного суб'єкта, колективного носія (народ, нація, професія, соціальна група тощо). Чи правомірні подібні трансформації? Так, правомірні, але лише за суворо певних умов (наприклад, у літературі, де ми часто, особливо в романі, знаходимо діалоги «мов» і мовних стилів) і за суворого та ясного методологічного усвідомлення» [2, с. 303, 297-298].

Методологічне усвідомлення, про яке говорить М. Бахтін, у музикознавчому контексті набуває великого значення, бо саме воно спонукає дослідника розуміти немузичні тексти композиторів як вагомих чинників формування смислових горизонтів їхніх музичних текстів, розглядати авторське слово в його вербальній формі як «знаряддя» пізнання його художнього вираження у звуковій формі. Тому з методологічного погляду виокремлення категорії авторського слова в окрему передумову та спеціальний інструмент вивчення «нової простоти» як стильової тенденції музичного мистецтва $є$ цілком закономірним. Тим більше, що історичному та художньо-естетичному контексту, у якому існує досліджуваний стильовий феномен, вищою мірою властивий діалогізм мовних стилів, що становить «суворо певні умови» (за М. Бахтіним) існування сучасного музичного мистецтва.

Теоретичне осмислення Автора й авторського слова як провідних категорій художньої культури здійснювалося в основ- 
ному в літературознавстві з різних методологічних позицій. Сьогодні теоретична розробка авторології ведеться на стику наукових дисциплін: літературознавства та лінгвістики, літературознавства й філософії. Різні підходи до неї породжені багатоаспектністю самого феномена автора, що творчо проявляє себе як композиційно, стилістично, так й онтологічно. Так, лінгвостилістична та філософсько-естетична концепції Автора й авторського слова представлені фундаментальними розробками В. Виноградова [3] і М. Бахтіна [2]. Лінгвістична спрямованість теорії В. Виноградова реалізується у сфері стилістики літературного твору, прагнення дослідника до вивчення індивідуальної мови письменника й мови твору актуалізує термін «образ автора», який є провідним для вченого. М. Бахтін, як відомо, бере за основу поняття «автор» і розглядає його як суб'єкт естетичної діяльності та як суб'єкт естетичного буття.

В. Виноградов пропонує вивчати образ автора як у плані діахронії («вглиб»), з урахуванням історії мови та зміни літературних шкіл і напрямів, так і «вшир» (у плані синхронії) на основі зіставлення творів низки сучасних письменників або творінь одного з них для виявлення динаміки образу автора в його творчості. У складній моделі «образу автора» В. Виноградов виділяє дві грані, що стали об'єктом його теоретичної рефлексії: перша пов'язана 3 поняттям стилю, друга - із суб'єктною сферою оповіді. Образ автора й розповідний стиль розуміються дослідником як взаємозумовлені категорії. Образ автора, на думку вченого, може визначатися стильовою або мовною «маскою», «личиною», яку свідомо використовує автор, довіряючи розповідь вигаданого оповідача. 3 іншого боку, образу автора відводиться головно організуюча функція, що формує весь стиль твору. У цьому випадку вибір стилю буде залежати від ідейної спрямованості й художнього змісту твору. Іншим аспектом категорії образу автора, що чітко позначений у працях В. Виноградова, стало вивчення образу автора в плані виявлення в тексті точок зору, позицій, суб'єктних сфер, «голосів» автора й персонажів у їх співвіднесеності один із одним. Саме із цим аспектом категорії «образ автора» тісно пов'язана проблема суб'єктивізації авторського слова. У сучасному літературознавстві та філології термін «образ автора» став одним із інструментів дослідження проблеми авторства. 
У теорії М. Бахтіна наявні три іпостасі автора: біографічний, первинний («автор-творець») і вторинний («образ автора») автор. «Автор-творець» являє собою категорію «особливого «позаестетичного» порядку», він знаходиться на кордоні створеного ним художнього світу. « <...> Це активна індивідуальність бачення й оформлення, а не видима та не оформлена індивідуальність», - пише вчений [2, с. 180]. Первинний автор визначається М. Бахтіним як «творча енергія», що створює у творі свій образ, «образ автора». Первинний автор, на його думку, учасник естетичної події, у якій зустрічаються в одній точці художник, незалежна від нього ціннісна реальність і читач, теж функціонує не як реальна особа, а як внутрішній об'єкт художнього акту. Вторинний автор - це поняття ієрархічне, вершину ієрархії в цьому випадку утворює авторська позиція, утілена в сюжетно-композиційній, просторово-часовій і жанровій структурі тексту. Саме з вторинним автором, за М. Бахтіним, герой може перебувати в визначених відносинах - виступати або як предмет зображення, або бути повноправним учасником діалогу.

Вступаючи в діалог із М. Бахтіним, його послідовник Б. Корман бачить у концепції «автора-творця» («автор як творець висловлювання») наявність прихованого уявлення «про суб'єктні іпостасі автора як єдино можливе його особистісне інобуття у творі» [6, с. 243]. У 1960-1970-і роки Б. Корманом створена оригінальна методика аналізу літературного тексту, що отримала назву «теорія автора» й пізніше була перейменована в роботах його учнів і послідовників у так званий «системно-суб’єктний підхід». Згідно з Б. Корманом, автор як носій концепції твору (саме це значення є ключовим для літературознавця) безпосередньо в текст не входить, звідси його опосередкованість суб'єктними або позасуб'єктними формами. Співвідношення автора біографічного й автора-суб’єкта свідомості, вираженням якого є твір, на думку Б. Кормана, «таке ж, як співвідношення життєвого матеріалу й художнього твору загалом: керуючись якоюсь концепцією дійсності й виходячи 3 певних нормативних і пізнавальних установок, реальний, біографічний автор <...> створює за допомогою уяви, відбору та переробки життєвого матеріалу автора художнього (концепірованого)» [6, с. 121].

Ще один послідовник бахтінської теорії, відомий літературознавець В. Кожинов розглядає автора як основного творчого 
суб'єкта твору, сутність якого виявляється в образі автора. У художньому тексті автор як творчий суб'єкт утілюється, як пише В. Кожинов, «уже не у формі образу, а у формі голосу автора - голосу, який проникає всю цілісність твору» [4, с. 26].

Очевидним $є$ те, що постать автора постає в названих концепціях як основна категорія тексту, вершина його системно-структурної організації. Будучи «осередком, фокусом цілого» (В. Виноградов), «конститутивним моментом художньої форми» (М. Бахтін), «концепірованим» елементом (Б. Корман), він $є$ тією творчою силою, яка визначає всі компоненти художнього твору (зміст, матеріал, форму) та ініціює їх перетворення з життєво-ситуативної площини в простір естетичних категорій і духовного буття людини. Цей факт зумовлює закономірність появи музикознавчих інтерпретацій проблеми автора в музичній творчості, і ширше - обгрунтування концепції авторського музикознавства як такого, що актуалізує методологічні потреби сучасного гуманітарного знання й відображає сучасний стан «науки про музику», яка в умовах глобалізованого світу все більш стає наукою про людину.

Цей напрям розвитку представлений дослідженнями О. Самойленко [9; 10], які спрямовані на розробку музикознавчої авторології як видово-спеціалізованого мистецького підходу до теорії автора в широкому гуманітарному полі міждисциплінарної методичної забезпеченості. Осмислення прагнення музикознавчої діяльності до авторства й розуміння постаті музикознавця як автора вибудовуються в концепції О. Самойленко на підставі іманентних властивостей музики як виду мистецтва, що володіє « <...> власною ноетикою - власними й вельми продуктивними способами створення вищих, «заповітних» і єдиних для родової та індивідуальної людської свідомості смислів, а також власними специфічними, невід'ємними від тканини музики, хронотопічними параметрами смислової реальності (ноосферної реальності), здатними суттєво впливати на долю культури» [9, с. 21]. Ще однією передумовою наближення музикознавчого слова до авторології виступають причини більш об’єктивного порядку, що пов'язані з новим пізнавальним рівнем сучасного музичного мистецтва: «Відтворюючи та організуючи на новому пізнавальному рівні матерію музики, пише О. Самойленко, - воно набуває здатності відкривати та вивчати найбільш суттєві сторони людського буття, най- 
більш важливі закономірності людської природи - iï сталі та динамічні екзистенційні якості» [10, с. 5]. I саме тому «всякий музикознавець повинен частково ставати мистецтвознавцем-літературознавцем, повинен не тільки чути й розуміти, а й дізнаватися (бачити) й аналізувати, а головне, розповідати й роз'яснювати. Так музикознавець стає автором, спостерігає відразу за трьома «героями» - життям - мистецтвом - i тими, хто його створює $<\ldots>$ » $[9$, с. 8$]$.

О. Самойленко акцентує принципову відмінність творчих установок автора-художника й автора-мистецтвознавця, що випливають із постулату М. Бахтіна про «реально-пізнавальну й етичну байдужість» автора-творця: «Від автора-музикознавця потрібно протилежне - реально-пізнавальна та морально-оціночна активність - епістемологічна включеність у цілісний процес сприйняття й впливу музики, що дає змогу створювати специфічні музикознавчі уявлення про цей процес» [9, с. 18]. Позначені авторські позиції О. Самойленко мають пряме методологічне відношення до дослідження композиторського вербального дискурсу як того носія музичної реальності, що втілений у словесно-понятійній формі, у Слові автора-творця, яке вміщає в собі й образ музики, й образ самого Автора, й образ тієї реальності, у якій вони існують. Прагнення почути, зрозуміти та роз'яснити композиторську вербальну мову має розгортатися в невід'ємності від авторської настанови музикознавця-дослідника на формування суто музикознавчих уявлень про композиторські рефлексії, які в сучасному музичному мистецтві представлені досить широко та різноманітно, узагалі становлять вагому частину європейського музичного мистецтва. Зазначена настанова, безумовно, сприяє розширенню пізнавальних обріїв музикознавчого дискурсу сучасності в загальному плані, оскільки 3 методологічного погляду вона може розумітися як те «знаряддя» пізнання, що дає можливості проникнення в глибинні смисли музичного тексту і творчої індивідуальності композитора, які органічно пов'язані між собою «тайною творчості» й повинні розумітися як «відображення» один одного. Ця ж настанова визначає й суто практичні завдання, які стоять перед сучасним дослідником музичного мистецтва хоча б в силу того, шо сьогодні музикознавство має в руках досить потужні інструменти освоєння музичної реальності, які відкривають можливості вирішення головної проблеми музи- 
кознавця як автора - «стати реальним, тобто повернути ідеальний сенс у реальність життя й мистецтва, довести його життєву та художню достовірність» [9, с. 20].

Авторське слово композиторів у розмаїтті своїх форм останнім часом усе частіше цікавить музикознавців (дослідження Б. Гецелєва, Н. Гуляницької, С. Савенко, Т. Франтової, О. Соколова, К. Чепеленко, О. Самойленко, І. Коновалової), звернення до цієї ланки авторепрезентації творчої індивідуальності митців становить наскрізну лінію сучасних підходів до вивчення музичного мистецтва.

Композитор, що пояснює та роз'яснює своє розуміння музики як мистецтва, свій погляд на музичну сучасність i свою «версію» музичної творчості, тобто пропонує образ автора-митця, зафіксований у Слові, - традиційна фігура для європейської музичної культури. Т. Франтова із цього приводу зауважує: «Слово композитора володіє особливою цінністю, бо це слово творця мистецтва. Але водночас це і слово людини з багатющим слуховим досвідом, знаннями, досконалим слухом, розвиненою інтуїцією, здатної миттєво проникнути в саме ядро складної проблеми. А образній яскравості й переконливості аналітичних спостережень композиторів музикознавці можуть позаздрити» [12, с. 260-261]. Авторське слово композиторів-сучасників представлено досить різноманітно, воно може бути максимально наближеним як до музикознавчого, так і до філософського; вираженим як у письмовій, так і в усній формі; може являти собою масштабну концепцію або ж інтимну сповідь; може бути епатажним чи, навпаки, украй традиційним. Таку різність вербального «образу композитора» зумовлено розмаїттям творчих індивідуальностей, що представляють музичне мистецтво сьогодення, у якому, на думку Т. Франтової «<...> не обійтися як без «чистих» музикознавців і композиторів, так і без універсалів, здатних до творчого самовираження в різних галузях. I нам ще тільки належить спробувати в майбутньому поставити проблему порівняння двох видів музичної науки - «композиторської» і «некомпозиторської» за своїм генезисом» [12, с. 262].

Кількісне накопичення композиторських вербальних текстів, яке створює сьогодні досить масштабну й автономну галузь текстів про музичне мистецтво та культуру загалом, закономірно потребує їх спеціального вивчення і ставить досить специфічні завдання перед музикознавцями, оскільки 
мова йде про своєрідне «відокремлення» усного та письмового слова композитора від його слова музичного, які апріорі $є$ взаємообумовленими й не можуть розумітися як самодостатні. Але ж цілком зрозуміло, що гуманітарна спрямованість сучасного музикознавства розв'язує цю проблему: дослідження композитора як «людини, що говорить» водночас $€$ дослідженням й автора, що створює словесний образ себе і своєї музики, а якщо ширше, сучасного стану буття музики як виду мистецтва та форми культурної свідомості. Тобто мова йде про досить продуктивний у методологічному сенсі підхід до вивчення композиторської постаті як суб'єкта й об'єкта музичного мистецтва, що дає можливості комплексного осягнення універсалізму автора музичного твору. Яскравим прикладом такого підходу є дисертаційне дослідження I. Коновалової «Феномен композитора в європейській музичній культурі XX століття: особистісні та діяльнісні аспекти» [5], що стало вдалою спробою музикознавчого осмислення парадоксальності і складності феномена композитора та різноманітності форм його творчої реалізації, кожна з яких по-своєму затребувана музичною культурою.

У досліджені І. Коновалова пропонує вивчення «культурного сенсу феномена композитора в дискурсі сучасної авторології» [5, с. 3], що дає їй змогу оперувати такими поняттями, як автор музичний та автор вербальний, які відображають особистісні й діяльнісні аспекти буття композитора в музичній культурі. Особливу увагу дослідниця приділяє автору вербальному, основною формою авторепрезентації якого є слово композитора, що розуміється як логос композитора й аналізується на прикладі композиторських вербальних текстів XX століття. I. Коновалова відзначає: «У вербальних посланнях, що є наслідком роботи індивідуальної свідомості, розкривається специфіка мислення і стилю композитора, діапазон і вектори його творчої діяльності, виявляються духовно-ментальні орієнтири та естетичні домінанти творчості. У цих текстах виявляється семантичний зв'язок із музичним авторським дискурсом і розкриваються інтелектуальні інтенції творців, які зумовлюють шляхи їхньої індивідуально-стильової еволюції» [5, с. 389]. Саме із цієї дослідницької настанови випливає функціональне значення вербальної автореалізації композитора як такого, що зумовлює « <..> лінгво-музичний контекст композиторської творчості, який концентрує ети- 
ко-естетичні й аксіологічні орієнтири, художницькі стратегії і творчі замисли митця, концептуально значущі ідеї і креативно-новаторські інтенції авторської свідомості», а також утворює «вербальні естетико-семіотичні об'єкти», які «є складником музичної комунікації» [5, с. 389]. Тобто І. Коновалова визначає функціональну специфіку вербальної діяльнісної сфери композитора (комунікативна та інформаційно-семантична [5, с. 391]) і пропонує свою дефініцію поняття вербальні тексти композиторів - це «конгломерат інформаційно насичених культурних артефактів і документальних утворень вербально-знакової комунікативної природи, що володіє власною кодовою системою, комунікативно-жанровим потенціалом, особливим прикордонним статусом між художніми та позахудожніми структурами, що є важливим естетико-семіотичним сегментом музичної культури» [5, с. 394].

У дослідженні I. Коновалової здійснена класифікація вербальних текстів композиторів за їх тематико-змістовною та функційною скерованістю: так, виокремлені художньо-естетичні тексти, філософсько-концептуальні, музично-теоретичні (аналітичні), музично-критичні, автобіографічні (мемуарно-епістолярні), публіцистичні, суспільно-комунікативні та методико-педагогічні. На думку авторки дослідження, усі ці різновиди співіснують на рівні інтертекстуальних зв'язків (як автономні тексти) і в комплексі утворюють гіпертекст [5]. У результаті ретельного дослідження специфічних властивостей і якостей вербальних текстів композиторів I. Коновалова доходить цілком логічного висновку, що вони є «особливо цінним естетико-семіотичним сегментом музичної й - ширше - гуманітарної культури» [5, с. 395], тим самим відкриваючи широку перспективу мистецтвознавчого дослідження композиторського вербального дискурсу сучасності.

Зазначена думка I. Коновалової співзвучна філософським роздумам М. Епштейна щодо специфіки гуманітарних наук, у смисловому колі яких, власне, і розгортається музикознавчий пізнавальний процес сьогодення. На думку М. Епштейна, гуманітарні науки є саморефлексуючими, оскільки в них сам суб'єкт пізнання - людина - стає предметом вивчення. «Парадокс автореференції стоїть у центрі гуманітарних наук, - пише вчений, - визначаючи складне співвідношення їх гуманітарності й науковості <...>. Суб'єкт людинознавства тому й не може бути повністю об'єктивованим, що знахо- 
диться в процесі становлення, і кожен акт самоопису є і подія його «самопобудови». У гуманістиці людина не тільки відкриває щось у світі суб'єктів, а й виробляє в ході самопізнання власну суб'єктивність» [13, с. 15-16]. Цікавим видається той факт, що один із найвидатніших представників композиторської словесної творчості сучасності В. Мартинов називає свої дослідження «автоархеологічними» й «музично-антропологічними» [7]. I якщо друге з авторських визначень цілком зрозуміле з погляду дослідницької установки його автора, то перше у смисловому значенні досить явно ілюструє ідею самопізнання за допомогою висловлювання про самого себе, принцип «зростання» своєї суб’єктивності в акті самоопису, про який говорить М. Епштейн. Здається, не тільки авторське слово В. Мартинова можна розглядати з такого погляду: незважаючи на той факт, що велика кількість композиторів не висловлювалася в такому концептуальному тоні щодо своєї мови «від першої особи», усе ж таки самий виток явища самоопису містить у собі ідею зустрічі із собою «зовнішнім» і «внутрішнім», тим, кого ти «вже знав», і тим, хто тобі відкривається в процесі висловлювання (говоріння).

I в цьому сенсі для об'ємного корпусу композиторських рефлексій, виражених за допомогою слова (письмового й усного), дуже показовим є зазначений принцип становлення, що відображає динаміку «самопобудови» своєї індивідуально-особистісної і творчої самосвідомості. Саме в цьому смисловому напрямі, на наш погляд, варто розглядати різноманітність авторської «подачі матеріалу» в кожному окремому випадку авторепрезентації видатних композиторів сучасності. Що ж стосується творчої постаті В. Мартинова (до речі, дуже «зручної» для дослідження динаміки становлення «образу автора» в його словесній творчості), то позначений принцип дійсно відчувається як у фундаментальних дослідженнях композитора, що становлять концептуальні підстави сучасного музикознавства, так і в його численних інтерв'ю та бесідах. У хронологічному континуумі в них можна відчути зміщення змістових і смислових акцентів, різну мовну інтонацію тощо, що пов'язано зі змінами внутрішніх уявлень про самого себе та про ті контексти, які породжують ці зміни.

Висновки. Орієнтованість сучасного музикознавства на дослідження проблеми Автора в музичній творчості та його вербального вираження, що втілюється в авторському слові 
композитора, актуалізує методологічні потреби сучасного гуманітарного знання й відображає сучасний стан «науки про музику», яка в умовах глобалізованого світу все більш стає наукою про людину. Прагнення почути, зрозуміти та роз'яснити Слово композитора $є$ неодмінною умовою формування суто музикознавчих уявлень про композиторські рефлексії, що в сучасному музичному мистецтві представлені досить широко й різноманітно. Зазначена настанова, безумовно, сприяє розширенню пізнавальних обріїв музикознавчого дискурсу сучасності в загальному плані, оскільки з методологічного погляду вона може розумітися як те «знаряддя» пізнання, що дає можливості проникнення в глибинні смисли музичного тексту і творчої індивідуальності композитора, які органічно пов'язані між собою «тайною творчості» й повинні розумітися як «відображення» один одного.

\section{СПИСОК ЛІТЕРАТУРИ}

1. Бахтин М.М. К философским основам гуманитарных наук. Собрание сочинений : в 7 т. Москва : Русские словари, 1997. Т. 5 : Работы 1940-х - начала 1960-х годов. 732 с.

2. Бахтин М.М. Эстетика словесного творчества. Москва : Искусство, 1979. 423 с.

3. Виноградов В.В. О теории художественной речи. Москва : Высшая школа, 1971. 240 с.

4. Кожинов В.В. Проблема автора и путь писателя (на материале двух повестей Юрия Трифонова). Контекст 1977: Литературнотеоретические исследования. Москва : Наука, 1978. С. 23-47.

5. Коновалова I. Феномен композитора в європейській музичній культурі XX століття: особистісні та діяльнісні аспекти : дис. ... докт. мистецтв : 26.00.01 «Теорія та історія культури» / Харківська державна академія культури. Харків, 2019. 630 с.

6. Корман Б.О. Избранные труды. Теория литературы. Ижевск : Институт компьютерных исследований, 2006. 552 с.

7. Мартынов В. Казус Vita Nova. Москва : Классика-XXI, 2010. $160 \mathrm{c}$.

8. Николаева Т.М. Текст. Лингвистический энциклопедический словарь. Москва : Советская энциклопедия, 1990. 685 с.

9. Самойленко А. Автор и герой в музыковедческой деятельности. Музикознавче слово в інформаційному контенті (пост) сучасності : матеріали Міжнародного музикознавчого семінару, Одеса, 11-17 червня 2018 р. Інформаційний сайт наукової частини Одеської національної музичної академії ім. А.В. Нежданової. URL: http://onmavisnyk.com.ua/pages/muzikoznavche-slovo-v-nformacinomu-kontent-postsuchasnost-2018.html. 
10. Самойленко О. Психологія мистецтва: сучасні музикознавчі проекції : монографія. Одеса : Видавничий дім «Гельветика», 2020. $236 \mathrm{c}$.

11. Толковый словарь русского языка : в 4 т. / ред. Д.Н. Ушаков. Москва : Советская энциклопедия, 1935-1940. Русская литература и фольклор : фундаментальная электронная библиотека. URL: http://feb-web.ru/feb/ushakov/ush-abc/19/us466710.htm?cmd=0\& istext $=1$.

12. Франтова Т.В. Изучение научного наследия композиторов как актуальная задача современного музыкознания. Фундаментальные исследования. 2014. № 12. С. 258-262.

13. Эпштейн М.Н. От знания - к творчеству. Как гуманитарные науки могут изменять мир. Москва ; Санкт-Петербург : Центр гуманитарных инициатив, 2016. 480 с.

\section{REFERENCES}

1. Bakhtin, M. (1997). To the philosophical foundations of the humanities. Collected works in 7 volumes. T. 5. Works of the 1940s - early 1960s. Moscow: Russian dictionaries [in Russian].

2. Bakhtin, M. (1979). Aesthetics of verbal creativity. Moscow: Art [in Russian].

3. Vinogradov, V. (1971). On the theory of artistic speech. Moscow: Higher School [in Russian].

4. Kozhinov, V. (1978). The problem of the author and the path of the writer (based on two stories by Yuri Trifonov). Context 1977: Literary theoretical studies. pp. 23-47. Moscow: Nauka [in Russian].

5. Konovalova, I. (2019). The phenomenon of the composer in the European musical culture of the XX century: special and professional aspects: dis... Doctor of Arts Criticism degree in specialty 26.00.01 theory and history of culture. Kharkiv State Academy of Culture. Kharkiv [in Ukrainian].

6. Korman, B. (2006). Selected Works. Literature theory. Izhevsk: Institute for Computer Research [in Russian].

7. Martynov, V. (2010). Casus Vita Nova. Moscow: Classics - XXI [in Russian].

8. Nikolaeva, T. (1990). Text. Linguistic Encyclopedic Dictionary. Moscow: Soviet Encyclopedia [in Russian].

9. Samoilenko, A. (2018). Author and Hero in Musicology. Materials of the International Musical Cognitive Seminar "Musical Cognitive Word in Information Content (Post) Success". Odessa, June 11-17. Information site of the scientific part of the Odessa National A. V. Nezhdanova Musical Academy. URL: http://onmavisnyk.com.ua/pages/muzikoznavche-slovov-nformac-inomu-kontent-postsuchasnost-2018.html [in Russian].

10. Samoilenko, O. (2020). Psychology of art: contemporary musical projects: monograph. Odessa: Publishing house "Helvetika" [in Ukrainian]. 11. Explanatory dictionary of the Russian language [Ed. D. N. Ushakov], (1935-1940). In 4 volumes. Moscow: Soviet Encyclopedia. 
Fundamental Electronic Library "Russian Literature and Folklore". URL: http://feb-web.ru/feb/ushakov/ush-abc/19/us466710.htm? cmd=0\&istext=1 [in Russian].

12. Frantova, T. (2014). Studying the scientific heritage of composers as an urgent task of modern musicology. Basic research. No. 12. pp. 258-262 [in Russian].

13. Epshtein, M. (2016). From knowledge to creativity. How the Humanities Can Change the World. Moscow; St. Petersburg: Center for Humanitarian Initiatives [in Russian].

УДК 78.071.1(477)(092):785.03

DOI https://doi.org/10.31723/2524-0447-2020-31-2-12

Ганна Серхї̈вна Савченко

ORCID: 0000-0002-9845-0450

кандидат мистецтвознавства, доцент, доцент кафедри композииії та інструментування Харківського національного університету мистецтв імені I. П. Котляревського lanna2@ukr.net

\section{ПРИЙОМИ ВТІЛЕННЯ ПЛАСТИЧНОСТІ ЯК «УНІВЕРСАЛІЇ» ОРКЕСТРОВОГО МИСЛЕННЯ I. СТРАВІНСЬКОГО (НА ПРИКЛАДІ «КОНЦЕРТНИХ ТАНЦІВ» ТА «БАЛЕТНИХ СЦЕН»)}

Мета роботи - систематизація оркестрових прийомів реалізації пластичності як однієї з універсалій оркестрового мислення I. Стравінського та принципу його оркестрового письма. Методологія дослідження. У роботі автор спирається на аналітичний, функиіональний, компаративний методи дослідження. Наукова новизна полягає в тому, що вперше в українському музикознавстві оркестрове письмо I. Стравінського досліджується в аспекті виявлення якісних характеристик пластичності й технічних прийомів його втілення. Висновки. У статті пластичність трактується як одна з «універсалій» (С. Савенко) оркестрового мислення I. Стравінського (разом із багатофігурністю та комбінаторністю), а також як властивість (якісна характеристика) його оркестрового письма. Під пластичністю розуміємо такі власти-

(C) Савченко Г. С., 2020 